\title{
COMPARATIVE OF THE EFFECTIVENESS OF APPLICATION PROBLEMS APPROACH WITH AND WITHOUT GUIDANCE IN UNDERSTANDING GEOMETRY LEARNING IN SMP NEGERI 2 PANGKAJENE
}

\author{
Nurhaeda P \\ Mathematics Education \\ Muhammadiyah University of Parepare \\ Indonesia
}

\author{
Agus \\ Mathematics Education \\ Muhammadiyah University of Parepare \\ Indonesia
}

\begin{abstract}
This research was an experimental research that began with the development of learning tools. Oriented learning tool with problem posing approach for Geometry material that was about Tube and Cone in class IX SMP.

This research aimed to (1) describe the effectiveness of learning with problem posing approach with guidance in learning mathematics in class IX SMP, (2) to describe the effectiveness of learning with problem posing approach without guidance in math lesson in class IX SMP, and (3) know the difference of the effectiveness of students taught using problem posing approach with guidance with the effectiveness of students taught using problem posing approach without guidance.

Subjects of this research were students of class IX SMP Negeri 2 Pangkajene of the even semester of academic year 2011/2012 which included eight parallel classes. It was randomly selected, one experimental class 1 and one experimental class 2. Experimental class 1 that was class IXD given learning with problem posing approach with guidance, while experimental class 2 that was class IXC given learning with problem posing approach without guidance.

Indicators of effectiveness of learning in this research were (1) learning results, (2) student's activities, and (3) student's response to learning. If the three indicators showed positive results, then the learning was categorized effective.

Based on descriptive and inferential analysis using $T$ Pired and Anakova test, it was concluded that learning with problem posing approach with guidance and problem posing approach without guidance was effective to use in teaching the material of tubes and cones in class IX SMP. And based on inferential statistical analysis by using anakova was also obtained the conclusion that the result of student learning taught using learning with problem posing approach with better guidance than result of student learning taught by approach of problem posing without guidance after purifying Spatial Capability Test and Early Capability Test. .
\end{abstract}

Keywords: Effectiveness, Problem Approach, and Geometry.

\section{INTRODUCTION}

The history of mathematical development has given many highly valuable facts to the reliability of mathematics in everyday life. Mathematics is not only for the purposes of calculation, but more than that mathematics has been widely used for the development of various sciences. Remembering the importance of mathematics is good so that math is taught in every level of education and it is an important lesson to master. But why math lessons is difficult, even a scourge for most students at school. Is it because of the mathematical representation that is too serious, and poor words, or because mathematics is more symbols, notations, and formulas that are not at all interesting. As Soedijarto puts it (in Sutriningsih 2001: 1) that experience of the educational systems in Indonesia, students are directly introduced formulas, without knowing how the formula was obtained. As a result, the child does not like science, there are even children who are afraid of the science.

One of the factors that caused mathematics to be difficult, both in terms of learning and in terms of teaching it, is the abstract nature and characteristic of mathematics that every theorem must be proved, and the language of mathematics that must be interpreted to understand its meaning, strategies, or appropriate methods.

Sullivan [1]says that the learning of mathematics in the classroom is generally concentrated only on the teacher, which causes the students to be lazy and less eager to receive the lesson. In line with that view, Sutiarso [1] "Students in general tend to accept only the transfer of knowledge from teachers and teachers in general just simply pass on knowledge information without engaging students in an active process".

Based on the above description, how should the task and role of teachers to help students understand the concept of mathematics that had been considered difficult?. [2] revealed 
that an effective teacher is to know how to make good planning. One is to plan and prepare a method of learning that provides opportunities for students to actively learn, both physically, mentally, and socially appropriate psychological development. Learning method in question is the method of problem-solving (problem posing) in a guided manner. The method is a way to develop an active way of learning. By compiling and solving itself, it is of course very possible results obtained more lasting in memory, and not easily forgotten by children, other than that the notion is found really mastered and easy to use or transferred in other situations.

Problem posing is one of non-conventional learning which in the process of activating the cognitive structure of students. This process is done by the students by linking the schemata they have, even some of the results of the study provide an illustration, that problem posing is one form of activities in learning mathematics that can activate students, develop students' thinking skills in solving problems, and generate positive attitude towards mathematics.

In line with it, Ruseffendi [3] says that to help a student in understanding the problem can be done by rewriting the problem in his own words, writing the matter in another form or in an operational form. Ruseffendi's suggested way is known as the problem posing, although the questions are based on existing or previous questions. This method needs to be implemented in the learning activities with attention to the signs of the implementation of learning activities. Based on the description above, the main focus of this research is to obtain: 1) description of the effectiveness of problem-solving approach with guidance in geometry learning in SMP Negeri 2 Pangkajene; 2) description of the effectiveness of the problemsolving approach without guidance in geometry learning in SMP Negeri 2 Pangkajene; and 3) To know whether there is any difference of effectiveness between approach of problem submission with guidance with without guidance in geometry learning in SMP Negeri 2 Pangkajene with attention to variables of early ability and spatial capability ..

\section{RESEARCH METHODS}

This study investigated the effectiveness of guided problem-solving methods, after considering the initial ability and spatial capability, and the effectiveness of the method without guidance. In accordance with Slavin's opinion [2] the effectiveness of learning in terms of student activity, positive student responses and can support the achievement of students' learning results, and support the ability of teachers to manage learning

\section{A. Research Design}

This research focused on the treatment and then wanted to know the effect of the treatment known as the experimental design. The design used in this research was randomized control group pretest-pretest design.
Table 1 of Research Design

\begin{tabular}{|c|c|c|c|c|}
\hline Groups & Test & Test & Treatment & Test \\
\hline Experiment & $\mathrm{T}_{1}$ & $\mathrm{~T}_{2}$ & $\mathrm{X}$ & $\mathrm{T}_{3}$ \\
\hline Control & $\mathrm{T}_{1}$ & $\mathrm{~T}_{2}$ & $\mathrm{Y}$ & $\mathrm{T}_{3}$ \\
\hline
\end{tabular}

Information:

T1: Initial ability test, before being treated

T2: Test the spatial ability, before being treated.

T3: Test the results of learning, after being treated.

$\mathrm{X}$ : Treatment / treatment of lesson submission with guidance Y: Treatment / treatment of lesson submission without guidance

This research used two sample groups, one group was defined as an experimental group and one group is defined as a control group. The variables in this research were as follows.

1) Free Variable

a) Treatment Variables, they were learning with method of filing of problem with guidance for experimental class and learning method without guidance for control class.

b) Controlled variables, they were material, teacher, and time. In this study, both of the experimental and control classes, taught by the same teacher, the time spent, and the materials taught during the learning activities are similar.

c) Companion Variables, they were initial ability, and spatial ability of the students on tube and cone material, before being given the treatment indicated by the student score of the initial test result, and the spatial test results.

\section{2) Dependent Variables}

The dependent variable in this research was the result of student learning after being given treatment. Students' learning results in question was the mastery of students to the material of the tube and cone obtained through learning by the method of filing the problem along with guidance shown by the score of test results learning.

\section{B. Research Subject}

The population in this research was the students of class IX SMP Negeri 2 Pangkajene consisting of 9 classes. Next, two classes of nine classes were selected randomly, as the research sample.

\section{Data Collection and Analysis Techniques}

To get the data needed in this research used data collection technique: 1) Observation (observation) to get data about student activity during KBM and teacher skill to manage learning. 2) Questionnaires to identify students' opinions on learning activities and 3) Test to obtain data achievement of learning results, initial ability and spatial ability of students.

Meanwhile, to answer the formulation of this proposed research problem, used three kinds of analytical techniques were: descriptive statistical analysis techniques, qualitative analysis, and inferential statistical analysis techniques. 


\section{RESULTS AND DISCUSSION}

\section{A. Research Results}

1) Comparison on Descriptive Analysis

Effectiveness indicators that were compared in descriptive analysis are student activity in learning and student responses to learning and learning tools.

\section{a) Learning results (Post test)}

Comparison of learning results was determined based on the posttest score as shown in the following table.

\section{TABLE 2 OF STUDENTS' ACTIVITIES COMPARISON}

\begin{tabular}{ccc}
\hline Class & $\begin{array}{c}\text { Average } \\
\text { Score }\end{array}$ & Category \\
\hline $\begin{array}{c}\text { Experiment } \\
\mathbf{1}\end{array}$ & 72,26 & High \\
$\begin{array}{c}\text { Ecperiment } \\
\mathbf{2}\end{array}$ & 65,81 & Fair \\
\hline
\end{tabular}

Based on the above table, it can be concluded that the students' learning results in the experimental class 1 was more effective than the student activity in the experimental class 2 which was marked by the average score of the students posttest in the experimental class 1 is greater than the average score of the students activity in the experimental class 2 that is $72,26>65,81$.

\section{b) Student activity}

Comparison of student activity was determined based on average score of observation aspect in each class as shown in the following table.

\section{(1.) Activity students The Students' Activity}

The comparison of students activity is determine based on the average score in observation aspect in each class as the table below:

TABLE. 3 THE COMPARISON OF STUDENTS' ACTIVITY

\begin{tabular}{ccc}
\hline Class & $\begin{array}{c}\text { Average } \\
\text { Score }\end{array}$ & Category \\
\hline $\begin{array}{c}\text { The First } \\
\text { Experiment } \\
\text { The Second } \\
\text { experiment }\end{array}$ & 3.4 & Good \\
\hline
\end{tabular}

The table shows that the students' activity in the first experiment is more effective than the students' activity in the second experiment, Because The total average score of the students' activity in the first experiment is higher than in the second experiment, it is $3,4>2,9$.

(2.) The Students' Respond

The Comparison the students' respond are determined based on the average score responses students on each class as it is looks on table follows.

The students' comparison
Table 4. The Comparison of The Students' Response

\begin{tabular}{ccc}
\hline Class & Average Score & Category \\
\hline $\begin{array}{c}\text { The First } \\
\text { Experiment }\end{array}$ & 3.8 & Positive \\
$\begin{array}{c}\text { The Second } \\
\text { experiment }\end{array}$ & 3.6 & Positive \\
\hline
\end{tabular}

The table shows that the students' activity in the first experiment is more effective than the students' activity in the second experiment, Because The total average score of the students' activity in the first experiment is higher than in the second experiment, it is $3,8>3.6$.

\section{(3.) The Comparison Analysis Inferential}

The indicator of effectiveness that is the results learning students based on results analysis inferential. The Analysis inferential begins with some of test test for data pre-test, post-test, and normality of gain score among others test normality and test homogeneity variance.

Normality test did for knowing whether the data is normal distribution or not. Then, the test homogeneity variance did for knowing the homogeneity variance from population.

\section{(a.)Test Normality}

Testing Normality Data is

the data results learning, the first capability test. The test is with test Kolmogorov-Smirnov ${ }^{a}$ SPSS 20.0 for Windows level and it based on the significance 0,05. Results test pre-test data normality can seen on Table follows.

Table 5. The Test Normality Of Experiment Class 1

\section{The Tests of Normality}

\begin{tabular}{|c|r|r|r|}
\hline \multirow{2}{*}{} & \multicolumn{3}{|c|}{ Kolmogorov-Smirnov ${ }^{\text {a }}$} \\
\cline { 2 - 4 } & Statistic & df & \multicolumn{1}{c|}{ Sig. } \\
\hline Value_Pretest_Eksp1 &, 121 & 31 &, $200 *$ \\
Value_Posttest_Eksp1 &, 144 & 31 &, 100 \\
Value_K.Ker_Eksp1 &, 119 & 31 &, $200 *$ \\
Value_K.Awal_Eksp1 &, 125 & 31 &, $200 *$ \\
\hline
\end{tabular}

a. Lilliefors Significance Correction

*. This is a lower bound of the true significance.

TABLE 6. TEST OF EXPERIMENT CLASS NORMALITY 2 The Tests of Normality

\begin{tabular}{|c|r|r|r|}
\hline & \multicolumn{3}{|c|}{ Kolmogorov-Smirnov ${ }^{\text {a }}$} \\
\cline { 2 - 4 } & Statistic & df & \multicolumn{1}{c|}{ Sig. } \\
\hline Value_pretest_Eksp2 &, 144 & 31 &, 100 \\
Value_posttest_Eksp2 &, 130 & 31 &, 199 \\
Value_K.Ker_Eksp2 &, 096 & 31 &, $200 *$ \\
Value_K.Awal_Eksp2 &, 111 & 31 &, $200 *$ \\
\hline
\end{tabular}

a. Lilliefors Significance Correction

*. This is a lower bound of the true significance.

Based on results output test normality variance with the using of test Kolmogorov-Smirnov ${ }^{a}$ on Table 5 and Table 6, the significance value for class experimental 1 and experimental 2 is higher than of 0,05 , then it could 
say that the experimental class normal distribution.

\section{(b.)The Test difference ability early (Pree-test)} experimental 1 class and experimental 2 class

The first experimental between both of the class are analyzed by using $t$-test, it is for knowing is there the difference pretest between experimental 1 class and experime ntal 2 class, the test results can seen on table follows.

TABLE 7. THE RESULT OF T-TEST IN THE EARLY DATA CAPABILITIES (PRE TEST) EXPERIMENTAL 1 CLASS AND EXPERIMENTAL 2 CLASS

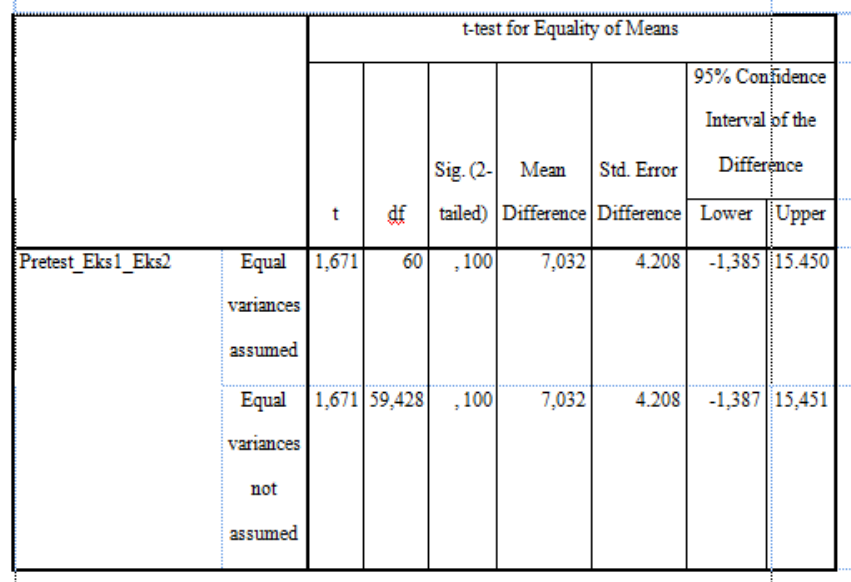

On Table 7 shows that the significance value (sig.2tailed) with $t$ - test is 0,100 , because the probability value is higher than 0,05 . It means that there is no the difference in the early ability between the students of experimental 1 class and experimental 2 class.

1. TheTest difference ability final (posttest) experimental cla ss and control class

The post-test from two classes are analyzed by using $t$ - test for knowing is there the difference ability for the post-test between class experimental and class control. The test results shows as on table following.

TABLE 8. THE RESULTS OF T-TEST IN THE FINAL DATA CAPABILITIES (POST-TEST) IN EXPERIMENTAL 1 CLASS AND EXPERIMENTAL 2 CLASS INDEPENDENT SAMPLES TEST

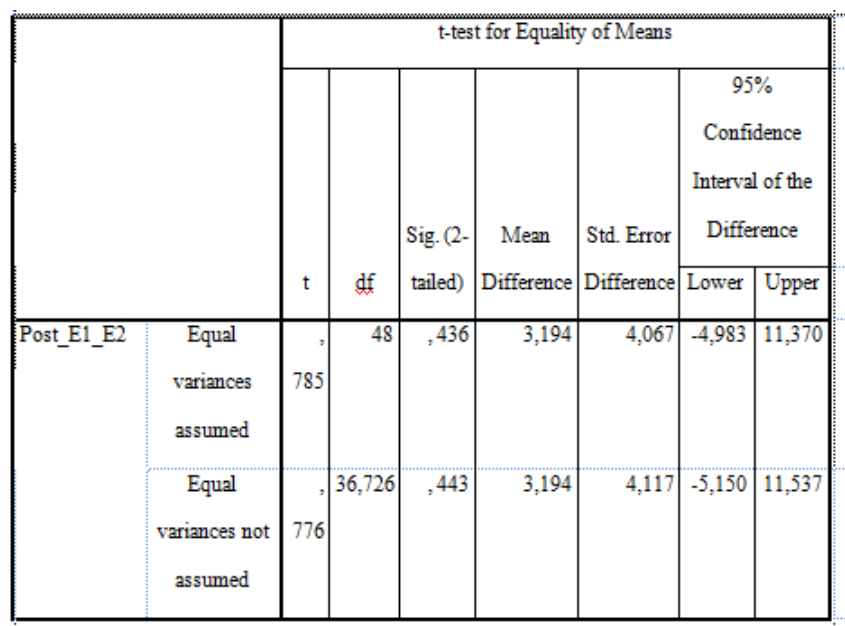

On Table 8 shows that thesignificance value (sig.2tailed) with $t$ - test is 0.436 because the probability value is lower than of 0.05. It means that there is no the difference post-test between students in experimental 1class and experimental 2 class.

\section{The Hypothesis Test (Test - $t$ )}

Thidepentionf \$amprespiest test shows that both of the variance either of the experimental 1 class (learning by applying problem posing approach with a guidance) and experimental 2 class (learning by applying problem posing approach without guidance) to provide information on the level $95 \%$ confidence, it can be concluded that both samples come of a homogeneous population. So, for testing the hypothesis used $t$ test. The test hypothesis is analyzed by sing $t$ - test for knowing is there the difference between enhancement results in learning mathematics in and experimental 2 class.

a) The Hypothesis Test of Major 1

"The Implementation of Problem posing approach with guidance effective by learning ge ometry on IX class at SMPN 2 Pangkajene "

The Major hypothesis 1 says that it is truth if all minor hypothesis in under is tested truth.

1.1. The Minor hypotheses about Indicator Learning Results 1.1.1.There is difference between post-test scores with material pre-

test scores geometry on experimental $1 \quad$ class (problem posing with guidance).

By statistical hypothesis formulated as following:

$\mathrm{H}_{\mathrm{o}} \quad$ against $\quad \mathrm{H}_{1}$ :

$=$ The average difference between pretest and post test score After the researcher analyzed the data, it can see output as table follows.

TABLE 9. THE RESULTS OF $T$ TEST IN $P$ RE-TEST AND POST-TEST IN EXPERIMENTAL 1 CLASS PAIRED SAMPLES TEST

\begin{tabular}{|c|c|c|c|c|c|c|c|}
\hline \multirow{3}{*}{\multicolumn{2}{|c|}{ I }} & \multicolumn{3}{|c|}{ Paired Differences } & $\mathrm{T}$ & df & $\begin{array}{l}\text { Sig. (2- } \\
\text { tailed) }\end{array}$ \\
\hline & & \multirow{2}{*}{$\begin{array}{c}\text { Std. Error } \\
\text { Mean }\end{array}$} & \multicolumn{2}{|c|}{$\begin{array}{l}95 \% \text { Confidence } \\
\text { Interval of the } \\
\text { Difference }\end{array}$} & & & \\
\hline & & & Lower & Upper & & & \\
\hline $\begin{array}{c}\text { Pair } \\
1\end{array}$ & $\begin{array}{c}\text { Value_Pretest_Eksp1 } \\
\text { Value_Posttest_Eksp1 }\end{array}$ & 1,420 & $-43,577$ & $-37,778$ & $-28,650$ & 30 &, 000 \\
\hline
\end{tabular}


The test Result of the hypothesis is done with t test by SPSS 20.0 for Windows use Paired Sample TTest with assumption second variance homogeneous(equal var iance assumed) and level significance of 0, 05, obtained the value of $\mathrm{P}$ (Sig.2-tailed) $0,001<\quad$. Therefore, it is rejected and $\mathrm{H}_{1}$ is accepted it means that there is the difference between post test scores and pretest scores geometry on experimental 1 class (problem posing with guidance) for teaching geometry in IX grade at SMPN 2 Pangkajene.

1.1.2. The average score of posttest material geometry on experimental 1 class (problem posing with guidance) exceeded in Criteria Minimal completeness (65).

By statistical hypothesis, this formulated as following:

$\mathrm{H}_{\mathrm{o}}$ against $\quad \mathrm{H}_{1}$ :

$=$ the average score of post test

Based on the results of descriptive analysis obtained an average post-test for the experimental 1 class is 72.26 , thus $\mathrm{H}_{\mathrm{o}}$ is rejected and $\mathrm{H}$ is ${ }_{1}$ accepted.

1.2. The hypotheses Minor about Indicator Activity Student "The Activities of students in learning geometry in experimental 1 class (the application of problem posing with guidance) has been seen with the categorized that the average score of activity students is at least 2.5 ".

Based on the results of descriptive analysis obtained average student activity for experimental 1 class relates with the categorized is 3.4 "good" thus the minor hypothesis about the student activity indicators are tested for truth.

1.3. The Minor hypotheses about Indicator Response Student

"The students' respond to problem posing approach with guidance on learning geometry located $i$ n category of "positive", for example is the average score of at least 3.5 ".

Based on the results of descriptive analysis obtained the average total student response for experimental 1 class is in the positive category of 3.8. Thus, the minor hypothesis of student responses is verified.

Minor third hypothesis is verified, thus The Implementation problem

posing approach with guidance effective in learning geometry in IX class at SMPN 2 Pangkajene

b) The Major Hypothesis Test 2

"The implementation of problem posing in approaching without guidance effective in learning geo metry in IX class at SMPN 2 Pangkajene ".

2. The major hypothesis says that the testing is truth if all minor hypothesis tested is truth.

1.1. The

\section{Minor hypotheses about Indicator Results Learn}

1.1.1. There is the difference between posttest scores with pre-test scores geometry on experimental 2

class (problem posing without guidance).
By hypothesis statistical this formulated as following:

$\mathrm{H}_{\mathrm{o}}$ : $\quad \mathrm{H}_{1:}=$ The average difference between pretest and post test score After the researcher analyzed the data processing, it can output as seen on table follows.

TABLE 10. THE RESULTS OF T TEST IN P RE-TEST AND POST-TEST IN EXPERIMENTAL 2 CLASS

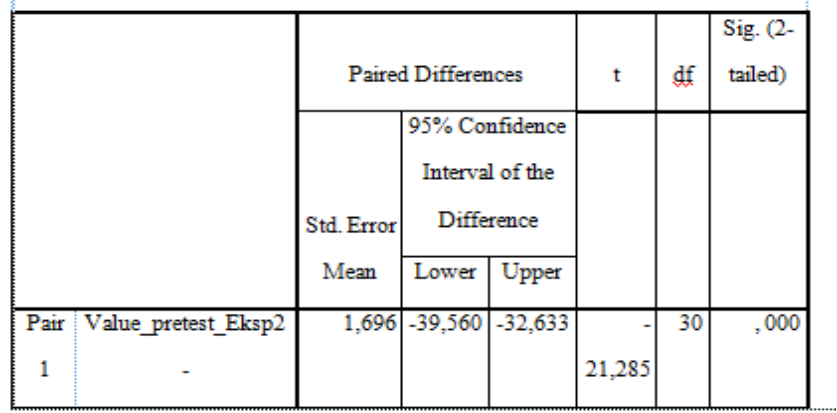

The testing results of the hypothesis is done with ttest by SPSS 20.0 for Windows used Paired Sample TTest with the second assumption variance homogeneous (equal variance assumed) and level significance of 0,05 , obtained the value of P (Sig.2-tailed) $0,001<\mathrm{a}_{\mathrm{c}}=$

0,05 . Therefore, $\mathrm{H}_{0}$ is rejected and $\mathrm{H}_{1}$ accepted, it means that there is the difference between post test scores with pretest scores geometry on experimental 2 cla ss (problem posing without guidance) for teaching geometry in IX class at SMPN 2 Pangkajene.

a) Test Major Hypothesis 2

"The implementation of problem posing approach without accompanied by effective guidance in the learning of geometry at IX grade students of SMPN 2 Pangkajene".

The major hypothesis 2 above is said to be true when all the minor hypotheses below are tested.

1.1. Minor Hypothesis on Indicators of Learning Result

1.1.1. There was a difference between the post test score and the pretest score of the geometry material in the experimental class II (problem posing without guidance). The statistically, this hypothesis was formulated as follows:

Ho: $\mu \_\mathrm{B}=0 \quad$ against $\mathrm{H} 1: \mu \_\mathrm{B}>0$ $\mu \_\mathrm{B}=$ average difference between pretest and post test scores

After finished the data processing, output display can be seen in following table. 
TABLE 11. RESULT OF UJIT-T DATA PRE-TEST AND POST-TEST OF EXPERIMENT CLASS 2

\section{PAIRED SAMPLES TEST}

\begin{tabular}{|c|c|c|c|c|c|c|}
\hline & \multicolumn{3}{|c|}{ Paired Differences } & $\mathrm{t}$ & $\mathrm{df}$ & $\begin{array}{l}\text { Sig. (2- } \\
\text { tailed) }\end{array}$ \\
\hline & \multirow{2}{*}{$\begin{array}{c}\text { Std. Error } \\
\text { Mean }\end{array}$} & \multicolumn{2}{|c|}{$\begin{array}{c}95 \% \text { Confidence } \\
\text { Interval of the } \\
\text { Difference }\end{array}$} & & & \\
\hline & & Lower & Upper & & & \\
\hline Value_posttest_Eksp2 & & & & & & \\
\hline
\end{tabular}

The result of hypothesis test with t-test through SPSS 20.0 for Windows program using Pired Sample T-Test with assumption of both variance assumed and significance level 0,05 , obtained $\mathrm{P}$ value (Sig.2-tailed) $0,001<\alpha=0.05$. Thus it was rejected and $\mathrm{H} 1$ accepted, it means there was a difference between the post test score and the pretest score of the geometry material in the experimental class 2 (problem posing without guidance) in teaching the geometry material in class IX grade students' of SMPN 2 Pangkajene.

1.1.2. The average post test score of geometric material in experiment II class (problem posing without guidance) extends beyond the Minimum Criterion of Completion (65).

Statistically, this hypothesis was formulated as follows:

Ho: $\mu_{-}=65$ against H1: $\mu_{-}>65$

$\mu_{-}=$post-test average score

Based on the results of descriptive analysis obtained the average post-test for experiment class 2 was 65.81, thus Ho was rejected and $\mathrm{H} 1$ accepted.

\subsection{Minor Hypothesis on Student Activity Indicators}

"The activity of students in geometry learning in experimental class II (application of problem posing without guidance) was consistent with the categorized with the average score of student activity at least 2.5".

Based on the results of descriptive analysis obtained the average of student activity for experimental class 2 was in accordance with the categorized that is 2.91 "good" thus the minor hypothesis about student activity indicators were tested correctness.

\subsection{Minor Hypothesis on Student Response Indicators}

"Student responses to problem posing approach without guidance on geometry learning were in the" positive "category where the average score of at least 3.5".

Based on the results of descriptive analysis obtained the average total student response for experiment class 2 was in the positive category of 3.6. Thus the minor hypothesis of student responses was verified.

b)Test Major Hypothesis 3
"The application of problem posing approach with guidance, more effective than without guidance in the learning of geometry in class IX SMPN 2 Pangkajene."

The 3 major hypothesis above was said to be validated if at least two of the three minor hypotheses below were tested. In the case of a minor hypothesis about the indicator of learning result declared true.

1.1. Minor Hypothesis on Indicators of Learning Result

"The mean score of students' geometric learning result taught by using problem posing approach with guidance was higher than without guidance, after taking into account the variables of covariate or control variables namely initial ability and spatial capability"

Statistically, this hypothesis was formulated as follows:

Ho: $\mu \_1=\mu \_2$ against $H 1: \mu \_1>\mu \_2$

$\mu_{-} 1=$ the average score of learning result of the student's geometry taught by using problem posing approach with guidance after taking into account the variables of covariate / control that were initial ability and spatial ability

$\mu \_2=$ average score of learning result of student's geometry taught by using problem posing approach without guidance after taking into account the covariate / control variables namely the initial ability and spatial ability

\subsection{Minor Hypothesis on Student Activity Indicators}

Student activity in learning geometry in class which was taught by using problem posing approach with guidance better than with without guidance.

Statistically, this hypothesis was formulated as follows:

$\bar{X}_{1}>\bar{X}_{2} \quad\left(\bar{X}_{1} \geq 2,5\right.$ and $\left.\bar{X}_{2} \geq 2,5\right)$

$\bar{X}_{1}=$ average score of student activity in learning taught by using problem posing approach with guidance after taking into account the covariate / control variables were initial capability and spatial capability.

$\bar{X}_{2}=$ the average score of student activity in learning taught by using problem posing approach without guidance after taking into account the covariate / control variables were the initial capability and spatial capability.

\subsection{Minor Hypothesis on Student Response Indicators}

Student responses in the learning of geometry in the class were taught by using problem posing approach with more positive guidance compared with without guidance.

Statistically, this hypothesis was formulated as follows:

$\bar{X}_{1}>\bar{X}_{2} \quad\left(\bar{X}_{1} \geq 3,5\right.$ and $\left.\bar{X}_{2} \geq 3,5\right)$

$\bar{X}_{1}=$ average score of students' responses in learning taught by using problem posing approach with guidance after taking into account covariate / control variables were initial capability and spatial capability.

$\bar{X}_{2}=$ average score of students' responses in learning taught by using problem posing approach with guidance after taking into account the covariate / control variables were initial ability and spatial capability.

Based on the results of comparison descriptive analysis of the average score of student responses on the experimental sequence 1 using approach posing problems with guidance was greater than the average score of student responses in experimental class 2 using problem posing 
approach without guidance, with a value of 3.8 and 3.6 or $\bar{X}_{1}>\bar{X}_{2} \quad$ so that the students' responses in geometry learning in the classroom were taught by using problem posing approach with more positive guidance than without guidance. By purifying the value of initial capability tests and spatial performance test scores.

\section{A. Development of Dictitious Designs}

The results showed that the application of mathematics learning with problem posing approach with guidance was more effective rather than mathematics learning with problem posing approach without accompanied by guidance material geometry on students of class IX SMPN 2 Pangkajene by purifying the spatial ability and initial ability test scores. This was in line with the Cockcroft -DES report, 1982 in Jasin's (1996) translation that the ability of each child varies greatly, so that different treatment will have different effects. The students who were accompanied by teachers in learning would feel happy to follow the lesson, more excited in doing the assigned tasks, thus impacting the achievement of maximum learning results.

\section{I. CONCLUSIONS AND SUGGESTIONS}

\section{A. Conclusion}

Based on the results of this research and discussion obtained some conclusions as follows:

1. Application of problem posing approach with guidance applied in experiment class 1 effective in learning of geometry in class IX SMPN 2 Pangkajene by purifying the influence of initial capability value and spatial capability.

2. Application of problem posing approach without guidance applied in experiment class 2 effective in learning of geometry in class IX SMPN 2 Pangkajene by purifying the influence of initial capability value and spatial capability.

3. Problem posing approach with guidance applied in experiment 1 class was more effective rather than problem posing approach without guidance applied in experiment class 2 by purifying the influence of initial capability and spatial ability.

\section{B. Suggestions}

Suggestions from the research conducted as input materials, among others described as follows:

1. Mathematics learning with the method of assigning the question of submission needs to be considered as one of the methods or approaches to improve student learning result in general and on the learning material geometry in particular.

2 . For the next researcher who are interested in developing this research, it is expected to pay close attention to the limitations of this research that has been developed, so the next researcher can improve the results of this research.

\section{REFERENCES}

[1] R. I. Arends, Clasroom Instruction and Management, New York: Mc Gran-Hill Book Co, 1997.

[2] S. Arikunto, Research Procedure, Jakarta: RinekaCipta, 2002.

[3] E. S. T. Y., Method of Giving Problem in mathematics Learning at MTS Negeri Rungkut Surabaya, Surabaya: PPS IKIP Surabaya, 1999.

[4] N. Surtaningsih, Kinesthetic Learning on Mathematics Subject, Surabaya: PPs Universitas Negeri Surabaya, 2001.

[5] H. Upu, Improving Ability to Solve Mathematical Problems of State Junior High School Student in Bandung through Problem Approach, Bandung: PPS UPI Bandung, 2003.

[6] A. Jasin, Translations of Effective Learning Books. By Richard Dunne \& Ted Wragg, Jakarta: Grasindo, 1996. 